\title{
Quantifying the third sector in Portugal: an overview and evolution from 1997 to 2007*
}

Ana Carvalho

Management Department, School of Economics and Management,

University of Minho, 4710-057 Braga, Portugal

Acknowledgements: I am grateful to the Portuguese Ministry of Labor and Social Solidarity, Statistics Department, for access to the data used in this study (Quadros de Pessoal). I would also like to express my gratitude to Miguel Reis Portela and Nelson Areal for their assistance in dealing with the database and STATA. I am also indebted to two anonymous reviewers for their useful comments on an earlier version of this paper.

\section{Abstract}

This paper presents a global overview of the third sector in Portugal drawing on data from a linked employer-employee database - "Quadros de Pessoal", which is based on a compulsory annual inquiry to organizations, making it a better source of information than those based on sample surveys and estimates. This study advances on previous overviews by providing more updated numbers for organization size, age, gross revenue and employment levels, as well as their distribution across the ICNPO third sector activity classification. The evolution of these variables from the period 1997-2007 is also analyzed.

The Portuguese third sector has been fast growing, with revenues amounting to $5.64 \%$ of Portugal's GDP and employment representing 4\% of the country's employment in 2007. It is mainly composed of very small organizations, with diminutive revenues. Perhaps its most striking features are the uneven distribution of employment and revenue and the strong concentration on Social services.

Keywords: third sector, non-profit organizations, Portugal, linked employer-employee database

* Published in Voluntas (2010) 21:588-610; DOI 10.1007/s11266-010-9157-1; The original publication is available at www.springerlink.com 
The third sector in Portugal has been largely understudied. Most existing work tends to focus on particular issues or specific types of third sector organizations, like IPSS (Instituição Privada de Solidariedade Social - social solidarity private institution) ${ }^{\mathrm{a}}$ status organizations (eg. Martins, 2000), cultural and artistic institutions (eg. Gomes, Lourenço and Martinho, 2006), or cooperatives (in this case, mainly sponsored by INSCOOP, an institution devoted to promoting cooperatives). To date, only two major studies provide a global overview of the third sector in Portugal: i) the survey carried out by Franco and her colleagues (Franco, Sokolowski, Hairel and Salaman, 2005) for the Johns Hopkins Comparative Nonprofit Sector Project; and (ii) the studies carried out under the scope of CIRIEC (CIRIEC, 2000; Chávez-Ávila and MonzónCampos, 2005). Based on these sources, we can tell that the third sector represented between $4 \%$ (Franco et al, 2005) and 4,4\% (Chávez-Ávila and Monzón-Campos, 2005) of total paid employment in Portugal and accounted for about 4,2\% of the Gross Domestic Product in 2002 (Franco et al, 2005). The Johns Hopkins study also shows that around $60 \%$ of this employment concentrates on service functions, particularly in social services (48\%) (which is considerably higher than in any other country in the comparative study, counterbalancing much lower concentrations on health and education). The later CIRIEC survey further reveals that cooperatives take up a little over $24 \%$ of third sector employment (Chávez-Ávila and MonzónCampos, 2005).

These studies are the only ones providing a quantified overview of the third sector in Portugal so far. However, they present numbers that are over 5 years old and have not since been updated. On the other hand, they are partly based on sample surveys that can be limited in their reach. They provide no real assurance of representativeness and some data must be inferred and estimated. Furthermore, and despite using Salamon and Anheier's (1997) International Classification of Nonprofit Organizations (henceforth ICNPO) as a reference, the Johns Hopkins study presents more aggregate data considering mainly the two major groups of Service and Expressive activities (Franco et al, 2005, p. 16).

In this paper we draw on a linked employer-employee Portuguese database (Quadros de Pessoal, compiled by the Ministry of Labor and Social Solidarity) to present an overall global picture of the third sector in Portugal, thus contributing to overcome a dearth of data on the area. Because Quadros de Pessoal is an annual universal survey of all organizations employing one or more people, we can expect to attain a picture of the third sector in Portugal much closer to 
its actual global dimension and internal composition. We also look at data from 10 consecutive years (from 1997 to 2007) so that we not only obtain an up-to-date depiction of the Portuguese third sector, but also a more dynamic view of its recent evolution. This general overview is essential, not only because it allows comparisons with other countries, but also because it provides the context against which more detailed and specific studies can be made and interpreted.

\section{USING “QUADROS DE PESSOAL"}

Quadros de Pessoal (QP) (which could translate as Personnel Records) is a linked employeremployee database compiled by the Portuguese Ministry of Labor and Social Solidarity since 1982. It is based on an annual survey of all private sector entities in the country employing one or more people. Public administration in general is not included, although companies and institutes owned by the State are. As the survey is of compulsory compliance, and despite excluding public employment, the resulting database provides an unparalleled source of nationwide information on private employment numbers and conditions, assuring a "high degree of coverage and reliability" (Blanchard and Portugal, 2000, p. 206), which justifies its widespread use in many important studies (eg.: Mata and Portugal, 2000; Martins, 2004). The data collected for QP referred to the last week of March between 1982 and 1993, and to the last week of October from 1994 on. At the employing establishment level, it includes information on such aspects as the identification, location and year of constitution, activity code and legal status, equity pattern, gross revenue and the number of people employed. And for each person employed, it provides data on gender and age, schooling and qualifications, occupation, wages, hours worked, type of employment contract held, part-time vs. full-time status, tenure and last promotion in the present employer. On the whole, this survey collected data from more than 350,000 establishments and over 3,2 million workers in 2007.

There are some limitations, however, in using this database. As mentioned above, it excludes most public employment, preventing the comparison between non-profit organizations and the public sector that would be interesting. On the other hand, the only information useful in identifying third sector organizations is the legal status, which can have its shortcomings as explained below. Moreover, only one (the main) activity is identified for each establishment, although it is common for some non-profit organizations to pursue multiple parallel ventures. 
Finally, QP includes only paid employees and establishments with at least one paid employee, excluding volunteers and organizations run entirely by volunteers.

\section{DEFINING THE THIRD SECTOR ON LEGAL STATUS}

Despite the growing interest and mounting work in the area, the definition of the third sector

remains an open topic ${ }^{b}$. There have been many contributions to defining the third sector, but we are yet to reach a consensual setting. More difficult than arriving at a conceptual definition seems to be establishing an operational means to identify and classify third sector organizations, which has contributed to restrict the production of more national-wide and even cross-national studies that provide an overall global picture of the third sector, as evidenced in Hodgkinson's (1999) book review.

In order to define which establishments to be considered in the third sector, legal status was used to classify organizations into for-profit private sector and third sector. QP contemplates 42 legal status categories (including a residual "other legal status" and an "ignored" categories), 16 of which can be considered as pertaining to the third sector (see Table I).

Laville et al. (1999) trace the historical roots of this legal approach to define the "third system" in Europe, and contrast it with an American definition more focused on a non-profit requirement. For them, this European definition centers not on the distribution of profits per se, but on the limits the legal status imposes on "private, individual acquisition of profits" and the fact that these organizations seek to generate "collective wealth rather than a return on individual investment” (p. 3). “Associations, co-operatives, mutual aid societies and foundations" are identified as the major types of organizations in the third sector, which Chávez and Monzón-Campos (2008, p. 18) also consider to be the "nucleus" of the Social Economy. Considering associations and foundations as third sector institutions is largely consensual, and Portuguese law discriminates among a variety of them, ranging from charity or humanitarian associations, cultural, sporting or recreational, professional or political associations, associations of companies that render services to its members and cannot distribute profits, as well as foreign associations. Foreign foundations acting in the country are also distinguished from national ones. People's Houses (Casas do Povo) were created to ensure the social, economical and cultural protection and development of rural workers and communities in the 1930's, under a clear corporatist philosophy, but have since 1976 evolved into public utility private 
organizations of an associative nature that seek to promote community development and wellbeing (Carvalho, 2008).

\section{Table I: Legal status categories in Portugal}

\begin{tabular}{|c|c|c|}
\hline QP Code & Legal status & Kind of organization \\
\hline 11 & $\begin{array}{l}\text { Charity and Humanitarian Association (Associação de Beneficiência e } \\
\text { Humanitária) }\end{array}$ & \\
\hline 12 & $\begin{array}{l}\text { Culture, Recreation and Sport Association (Associação de Cultura, } \\
\text { Recreio e Desporto) }\end{array}$ & \\
\hline 13 & Political Association (Associação Politica) & \\
\hline 14 & $\begin{array}{l}\text { Employer or Trade-union Association (Associação Patronal ou } \\
\text { Sindical) }\end{array}$ & Association \\
\hline 15 & $\begin{array}{l}\text { Non-union Professional Association (Associação Profissional não } \\
\text { Sindical) }\end{array}$ & \\
\hline 16 & People's House (Casa do Povo) & \\
\hline 18 & Other Associations (Outras Associações) & \\
\hline 36 & $\begin{array}{l}\text { Complementary Group of Enterprises (Agrupamento Complementar de } \\
\text { Empresas) }\end{array}$ & \\
\hline 37 & $\begin{array}{l}\text { European Group of Economic Interest - Civil (Agrupamento Europeu } \\
\text { de Interesse Economico - Civil) }\end{array}$ & \\
\hline 72 & Foreign Association (Associação Estrangeira) & \\
\hline 74 & Foreign Civil Enterprise (Sociedade Civil Estrangeira) & \\
\hline 17 & Mutual Aid Association (Associação de Socorros Mútuos) & Mutual aid society \\
\hline 19 & National Foundation (Fundação Nacional) & \\
\hline 73 & Foreign Foundation (Fundação Estrangeira) & Foundation \\
\hline 41 & Cooperative Society (Sociedade Cooperativa) & Cooperative \\
\hline 61 & Religious Collective Person (Pessoa Colectiva Religiosa) & Religious \\
\hline
\end{tabular}


The inclusion of mutual societies and cooperatives in the third sector is more contentious, even within Europe. The legal framing of these institutions varies considerably across European Union countries, and cooperatives, for instance, can take the form of commercial companies as well as civil associations (Chávez-Ávila and Monzón-Campos, 2005). Chávez and MonzónCampos (2008: 18) state that in some countries certain nonprofit organizations "do not recognize themselves as being integral parts of this social sector; on the contrary, they assert their idiosyncrasy and isolation." According to the authors, this would partially be the case of cooperatives in Portugal. Nevertheless, the Portuguese Constitution distinguishes between a "public", a "private" and a "cooperative and social" sectors of the economy (CRP, 2005), implying that cooperatives are more akin to the third sector than to the other two. In this study, cooperatives are included in the nonprofit group.

As for mutual societies, although they are originally based on the spirit of solidarity among members, some have evolved into large insurance and banking institutions quite indistinct from private for profit companies. On the other hand, this group includes organizations whose main purpose is to benefit its members and the community. For the purpose of this study, Mutual Aid Associations (Associação de Socorros Mútuos) were included in the third sector, whereas the Mutual Agricultural Credit Bank (Caixa de Crédito Agrícola Mútuo) and Economic Bank (Caixa Económica) categories were excluded.

Religious organizations (Pessoa Colectiva Religiosa) have a legal status of their own in Portugal. Although European authors (eg: Defourny and Develtere, 2000; Chávez and MonzónCampos, 2005, 2008) tend not to consider them specifically, they do recognize the marked influence of religion on the social economy. The Johns Hopkins studies include religious organizations, although they attempt to distinguish between worship and service activities (Salamon and Anheier, 1996). Here, religious organizations were included.

\section{DATA AND VARIABLES}

QP gathers a wide range of data. For the purpose of providing a global description of the third sector in Portugal, the following variables are used: legal status (as described above), CAE (the economic activity classification, which will be used to classify the organizations into ICNPO), number of employees, gross revenue, establishment size and age. The data presented in this paper is primarily for the year 2007, the latest year available, but the variation relative to five 
(2002) and ten years (1997) previous are analyzed and presented for the number of organizations, employment level and gross revenue.

The activity codes provided by QP are based on the CAE system (Economic Activities Classification, Rev. 2.1 up to 2006 and Rev. 3 from 2007 on), commonly used in Portugal, which closely resembles the European classification NACE (CAE Rev. 3 improves on this similarity) and the United Nations standard ISIC. In order to make the CAE classification relevant for the third sector, it was converted into the first level 12 category version of ICNPO (Salamon and Anheier, 1997), following the correlation tables between ICNPO and ISIC offered by the United Nations' Handbook on Nonprofit Institutions in the System of National Accounts (2003). Unlike those tables, however, the objective here is not to fit the ICNPO into ISIC/CAE, but the other way around, making the conversion not entirely straightforward. Many important $\mathrm{CAE}$ activities (such as agriculture, commerce and most manufacturing industries) are not covered by these conversion tables, resulting in the bulging of what should be a residual ICNPO Group 12 ("Not elsewhere classified"). Moreover, more than one ISIC categories spread out through different ICNPO Groups (eg: “Activities of other membership organizations n.e.c.”), which is not only a problem in itself but also accounts for the difficulties in filling ICNPO Group 8 (Philanthropic intermediaries and voluntarism promotion). There are no specific CAE (or ISIC) categories for philanthropic or voluntarism promotion activities. The UN tables make Group 8 out of ISIC residual categories such as "Other financial intermediation n.e.c." and "Activities of other membership organizations n.e.c.", which works when fitting the ICNPO into ISIC, but not when doing the opposite, as those residual categories might also fit other ICNPO categories (for instance, "Activities of other membership organizations n.e.c." appear in ICNPO groups 6, 7, 8 and 9).

These difficulties notwithstanding, a correspondence table was produced (Table II), where the CAE Rev. 3 codes provided by QP are matched to ICNPO groups.

Gross revenue, establishment size and age were all categorized to allow for more expedient analysis. Gross revenue values were grouped into 10 categories, as shown in Table III. This classification overly emphasizes small size revenues because most third sector organizations present low revenues, reflecting the prominence of micro and small sized establishments. The uppermost limit of 2,500 million Euros was based on the analysis of QP data, as no establishment exceeds that amount in revenue. 
Table II: Correspondence table between the ICNPO and the Portuguese CAE Rev. 3

\begin{tabular}{|c|c|c|c|}
\hline \multicolumn{2}{|c|}{ ICNPO } & \multicolumn{2}{|c|}{ Portuguese CAE Rev. 3} \\
\hline \multirow{14}{*}{1} & \multirow{14}{*}{ Culture and recreation } & 017 & $\begin{array}{l}\text { Hunting, species repopulation and related service } \\
\text { activities }\end{array}$ \\
\hline & & 18 & Publishing, printing and reproduction of recorded media \\
\hline & & 55 & Accommodation \\
\hline & & 56 & Food and beverage service activities \\
\hline & & 59 & Cinema, video, television and sound production \\
\hline & & 60 & Television and radio broadcasting \\
\hline & & & \\
\hline & & 79 & $\begin{array}{l}\text { Travel and tourist agencies and other tourist assistance } \\
\text { activities }\end{array}$ \\
\hline & & 90 & $\begin{array}{l}\text { Theater, music, dance and other artistic and literary } \\
\text { activities }\end{array}$ \\
\hline & & $\begin{array}{l}91 \text { (except } \\
9104)\end{array}$ & $\begin{array}{l}\text { Libraries, archives, museums and other cultural } \\
\text { activities }\end{array}$ \\
\hline & & 92 & Lotteries and other betting games \\
\hline & & 93 & Recreational, cultural and sports activities \\
\hline & & 94991 & Cultural and recreational associations \\
\hline & & 94993 & Youth and student associations \\
\hline \multirow{3}{*}{2} & \multirow{3}{*}{ Education and research } & 72 & Scientific research and development \\
\hline & & 85 & Education \\
\hline & & 94994 & Parents and education guardians' associations \\
\hline 3 & Health & 86 & Human health activities \\
\hline 4 & Social services & 87 & Social work activities with lodging \\
\hline
\end{tabular}




\begin{tabular}{|c|c|c|c|}
\hline & & 88 & Social work activities without lodging \\
\hline & & 84240 & Public order and safety activities \\
\hline & & 84250 & Civil protection activities \\
\hline & & 84300 & Compulsory social security \\
\hline & & 38 & $\begin{array}{l}\text { Sewage and waste collection, treatment and disposal } \\
\text { activities; waste revaluation }\end{array}$ \\
\hline & & 39 & Decontamination and similar activities \\
\hline & & 75 & Veterinary activities \\
\hline & & 9104 & $\begin{array}{l}\text { Activities of botanical and zoological gardens, } \\
\text { aquariums and natural reserves }\end{array}$ \\
\hline & & 94992 & Environmental defense associations \\
\hline & & 35 & $\begin{array}{l}\text { Electricity, gas, steam and hot water production and } \\
\text { supply }\end{array}$ \\
\hline & & 36 & Water collection, treatment and supply \\
\hline & & 41 & Real estate development \\
\hline & & 42 & Civil engineering \\
\hline & & 43 & Specialized construction activities \\
\hline & & 49 & Land transport and transport via pipelines \\
\hline 6 & Development and housing & 50 & Water transport \\
\hline & & 51 & Air transport \\
\hline & & 52 & $\begin{array}{l}\text { Storage and other support activities for transportation } \\
\text { (including handling) }\end{array}$ \\
\hline & & 53 & Postal and courier services \\
\hline & & 61 & Telecommunications \\
\hline & & 62 & $\begin{array}{l}\text { Informatics consulting, programming and related } \\
\text { activities }\end{array}$ \\
\hline
\end{tabular}




\begin{tabular}{|c|c|c|c|}
\hline & & 63 & Information service activities \\
\hline & & 64 & $\begin{array}{l}\text { Financial intermediation, except insurance and pension } \\
\text { funds }\end{array}$ \\
\hline & & 65 & $\begin{array}{l}\text { Insurance, reinsurance and pension funds, except } \\
\text { compulsory social security }\end{array}$ \\
\hline & & 66 & Activities auxiliary to financial intermediation \\
\hline & & 68 & Real estate activities \\
\hline & & 6920 & Accounting and auditing activities; tax consulting \\
\hline & & 70 & Holding companies and management consulting \\
\hline & & 71 & $\begin{array}{l}\text { Architecture and engineering; technical tests and } \\
\text { analysis }\end{array}$ \\
\hline & & 73 & Publicity, market research and opinion polls \\
\hline & & 74 & $\begin{array}{l}\text { Other consulting, scientific, technical or similar } \\
\text { activities }\end{array}$ \\
\hline & & 77 & Rental and leasing activities \\
\hline & & 78 & Employment agencies \\
\hline & & 80 & Investigation and security activities \\
\hline & & 81 & Building and gardening maintenance \\
\hline & & 82 & Other services activities provided to businesses \\
\hline & & 6910 & Legal and notary activities \\
\hline 7 & Law, advocacy and politics & 84230 & Justice \\
\hline & & 94920 & Political organizations \\
\hline 8 & $\begin{array}{l}\text { Philanthropic intermediaries } \\
\text { and } \\
\text { voluntarism promotion }\end{array}$ & & \\
\hline 9 & International & 99 & Activities of extraterritorial organizations and bodies \\
\hline
\end{tabular}




\begin{tabular}{|c|c|c|c|}
\hline 10 & Religion & 9491 & Religious organizations \\
\hline 11 & $\begin{array}{l}\text { Business and professional } \\
\text { associations, unions }\end{array}$ & 941 & $\begin{array}{l}\text { Activities of trade unions, employers' and professional } \\
\text { organizations }\end{array}$ \\
\hline \multirow{21}{*}{12} & \multirow{21}{*}{ Not elsewhere classified } & $\begin{array}{l}01 \text { (except } \\
017)\end{array}$ & $\begin{array}{l}\text { Agriculture, animal production, hunting and related } \\
\text { service activities }\end{array}$ \\
\hline & & 02 & Forestry, logging and related service activities \\
\hline & & 03 & Fishing and aquaculture \\
\hline & & 05 & Mining of coal and lignite \\
\hline & & 06 & Extraction of crude petroleum and natural gas \\
\hline & & 07 & Mining of metal ores \\
\hline & & 08 & Other mining and quarrying \\
\hline & & 09 & Services related to mining and quarying \\
\hline & & 10 & Manufacture of food products \\
\hline & & 11 & Manufacture of beverages \\
\hline & & 12 & Manufacture of tobacco products \\
\hline & & 13 & Manufacture of Textiles \\
\hline & & 14 & Manufacture of apparel \\
\hline & & 15 & Manufacture of leather and related products \\
\hline & & 16 & Manufacture of wood and cork products \\
\hline & & 17 & Manufacture of paper and its products \\
\hline & & 19 & $\begin{array}{l}\text { Manufacture of coke, refined petroleum and nuclear fuel } \\
\text { products }\end{array}$ \\
\hline & & 20 & $\begin{array}{l}\text { Manufacture of chemicals and synthetic fibers, except } \\
\text { pharmaceutical products }\end{array}$ \\
\hline & & 21 & Manufacture of pharmaceutical products \\
\hline & & 22 & Manufacture of rubber and plastic products \\
\hline & & 23 & Manufacture of other non-metallic mineral products \\
\hline
\end{tabular}




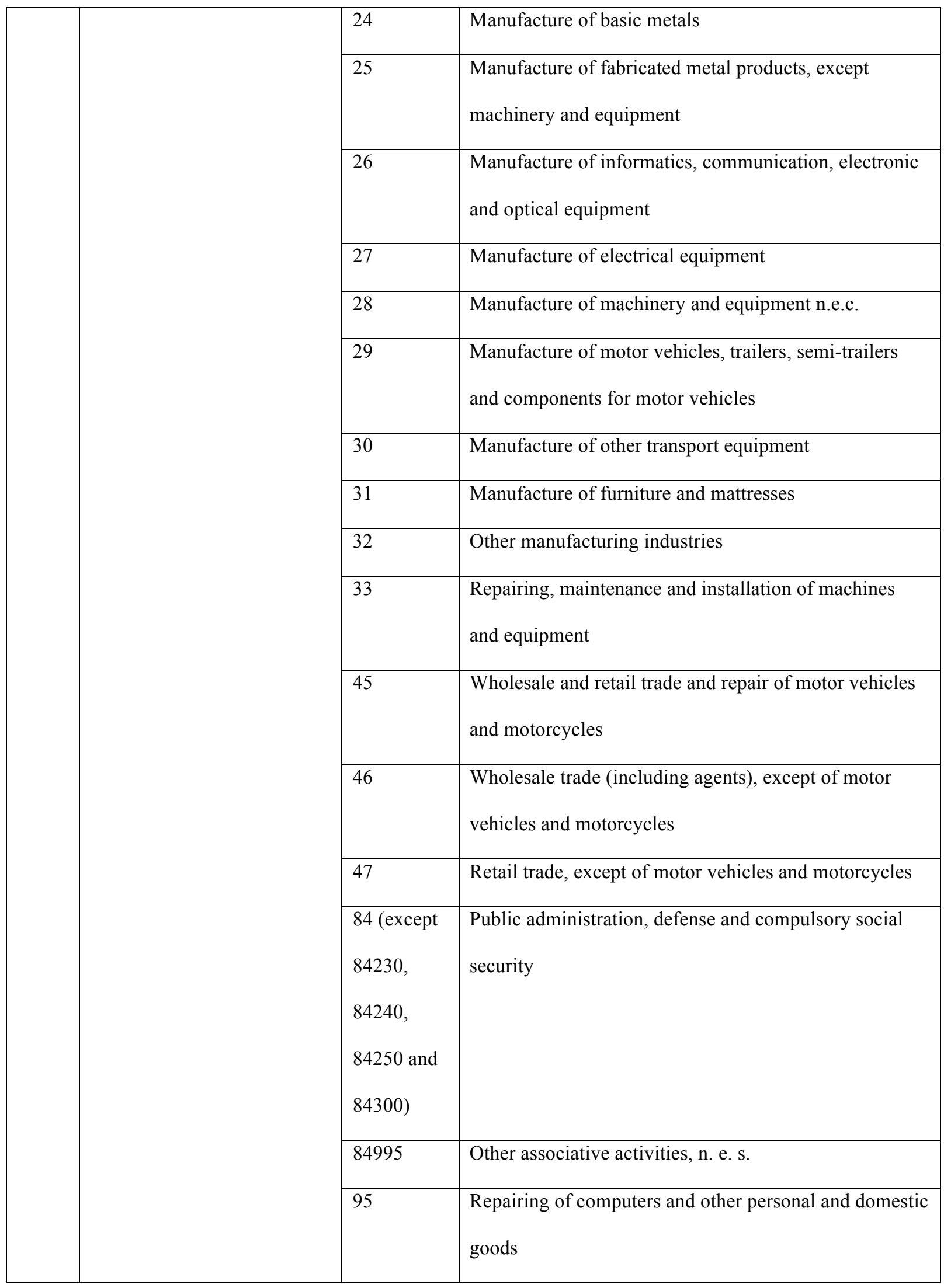




\begin{tabular}{|l|l|l|l|}
\hline \multirow{nnyy}{*}{} & 96 & Other personal services \\
\cline { 3 - 4 } & 97 & $\begin{array}{l}\text { Activities of households as employers of domestic } \\
\text { personnel }\end{array}$ \\
\cline { 3 - 4 } & & 98 & $\begin{array}{l}\text { Goods or service-producing activities of private } \\
\text { households for own use }\end{array}$ \\
\cline { 3 - 4 } & & \\
\cline { 3 - 4 } & & \\
\cline { 3 - 4 } & & \\
\hline
\end{tabular}

Table III: Gross revenue categorization

\begin{tabular}{ll}
\hline Category & \multicolumn{1}{c}{ Revenue } \\
& (in thousands of Euros) \\
\hline 1 & Less than 10 \\
2 & 10 to 100 \\
3 & 100 to 1,000 \\
4 & 1,000 to 2,000 \\
5 & 2,000 to 10,000 \\
6 & 10,000 to 50,000 \\
7 & 50,000 to 100,000 \\
8 & 100,000 to 500,000 \\
9 & 500,000 to $1,000,000$ \\
10 & $1,000,000$ to $2,500,000$ \\
\hline
\end{tabular}

Establishment size was categorized according to the European Commission Recommendation (European Commission, 2003) concerning the definition of small and medium-sized enterprises (SMEs), as shown in Table IV. 
Table IV: Establishment size categorization

\begin{tabular}{lll}
\hline Category & $\begin{array}{l}\text { Number of } \\
\text { Employees }\end{array}$ & $\begin{array}{l}\text { Annual Turnover/Total } \\
\text { Balance Sheet }\end{array}$ \\
& & $\leq$ EUR 2 million \\
\hline Micro-sized enterprises & $<10$ & $\leq$ EUR 10 million \\
Small-sized enterprises & $<50$ & $\leq$ EUR 50 million/43 million \\
Medium-sized enterprises & $<250$ & \\
Large-sized enterprises & $\geq 250$ & \\
\hline
\end{tabular}

Establishment age was considered in 7 categories, as shown in Table V.

Table V: Establishment age categorization

\begin{tabular}{ll}
\hline Category & Organization age \\
\hline 1 & less than 3 years \\
2 & 3 to 5 years \\
3 & 5 to 10 years \\
4 & 10 to 20 years \\
5 & 20 to 50 years \\
6 & 50 to 100 years \\
7 & more than 100 years \\
\hline
\end{tabular}

\section{QUANTIFYING THE THIRD SECTOR IN PORTUGAL}

The data described above allow us to display a detailed description of the third sector in Portugal. Overall, in 2007 there were 10,123 third sector organizations employing 208,821 people. This corresponds to about $4 \%$ of the employed population (considering the employment numbers provided by INE, 2008a). Although this represents a similar proportion of total employment as reported by Franco et al. (2005) for 2002, the employment level in the third sector has grown from 2002 to 2005 in about $33.66 \%$.

The aggregate gross revenue for the sector was 9,193,400 million Euros, which represents 
$5.64 \%$ of the 2007 Portuguese GDP (considering the GDP numbers provided by INE, 2008b). These figures spread quite unevenly throughout the sector though. Table VI shows the distribution of organizations and employment by relevant third sector legal status.

Table VI: Distribution of the third sector by legal status (2007)

\begin{tabular}{|c|c|c|c|c|}
\hline \multirow[b]{2}{*}{ Legal Status } & \multicolumn{2}{|c|}{ Number of organizations } & \multicolumn{2}{|c|}{ Number of people employed } \\
\hline & number & percentage & number & percentage \\
\hline $\begin{array}{l}\text { Charity and Humanitarian Association } \\
\text { (Associação de Beneficiência e Humanitári }\end{array}$ & 3156 & 31.18 & 103556 & 49.59 \\
\hline $\begin{array}{l}\text { Culture, Recreation and Sport Association } \\
\text { (Associação de Cultura, Recreio e Desportc }\end{array}$ & 1465 & 14.47 & 10359 & 4.96 \\
\hline $\begin{array}{l}\text { Political Association } \\
\text { (Associação Politica) }\end{array}$ & 4 & 0.04 & 431 & 0.21 \\
\hline $\begin{array}{l}\text { Employer or Trade-union Association } \\
\text { (Associação Patronal ou Sindical) }\end{array}$ & 884 & 8.73 & 9069 & 4.34 \\
\hline $\begin{array}{l}\text { Non-union Professional Association } \\
\text { (Associação Profissional não Sindical) }\end{array}$ & 98 & 0.97 & 951 & 0.46 \\
\hline $\begin{array}{l}\text { People's House } \\
\text { (Casa do Povo) }\end{array}$ & 236 & 2.33 & 2486 & 1.19 \\
\hline $\begin{array}{l}\text { Mutual Aid Association } \\
\text { (Associação de Socorros Mútuos) }\end{array}$ & 55 & 0.54 & 1371 & 0.66 \\
\hline $\begin{array}{l}\text { Other Associations } \\
\text { (Outras Associações) }\end{array}$ & 1629 & 16.09 & 19142 & 9.17 \\
\hline $\begin{array}{l}\text { National Foundation } \\
\text { (Fundação Nacional) }\end{array}$ & 249 & 2.46 & 9531 & 4.56 \\
\hline Complementary Group of Enterprises & 112 & 1.11 & 3214 & 1.54 \\
\hline
\end{tabular}


(Agrupamento Complementar de Empresas)

European Group of Economic Interest - Civil

0

0.00

0

0.00

(Agr. Europeu de Interesse Económico - Civil)

Cooperative Society

1304

12.88

25547

12.23

(Sociedade Cooperativa)

Religious Collective Person

926

9.15

23067

11.05

(Pessoa Colectiva Religiosa)

Foreign Association

3

0.03

34

0.02

(Associação Estrangeira)

Foreign Foundation

2

0.02

63

0.03

(Fundação Estrangeira)

Foreign Civil Enterprise

0

0.00

0

0.00

(Sociedade Civil Estrangeira)

Total

10123

100.00

208821

100.00

The most significant legal status is Charity and Humanitarian Association, accounting for nearly a third (31.18\%) of all third sector organizations, and employing half $(49.59 \%)$ of third sector employees. Culture, Recreation and Sport Associations (14.47\%) and Other Associations $(16.09 \%)$ represent the next larger groups, followed by Cooperatives $(12.88 \%)$, which are nonetheless the second largest employers (12.23\%). Religious organizations, although only fifth in number, are the third in employment (11.05\%). European Groups, Foreign institutions and Political Associations are the least numerous organizations, and they also employ the least number of people.

Perhaps of more interest is the distribution per activity (Figures 1 and 2). Tables VII and VIII display the distribution and growth of the number of organizations and of employment, respectively, by ICNPO activity. Table IX presents the aggregate gross revenue by ICNPO and 
its evolution.

Figure 1: Third sector organizations by activity (ICNPO) (in percentage)

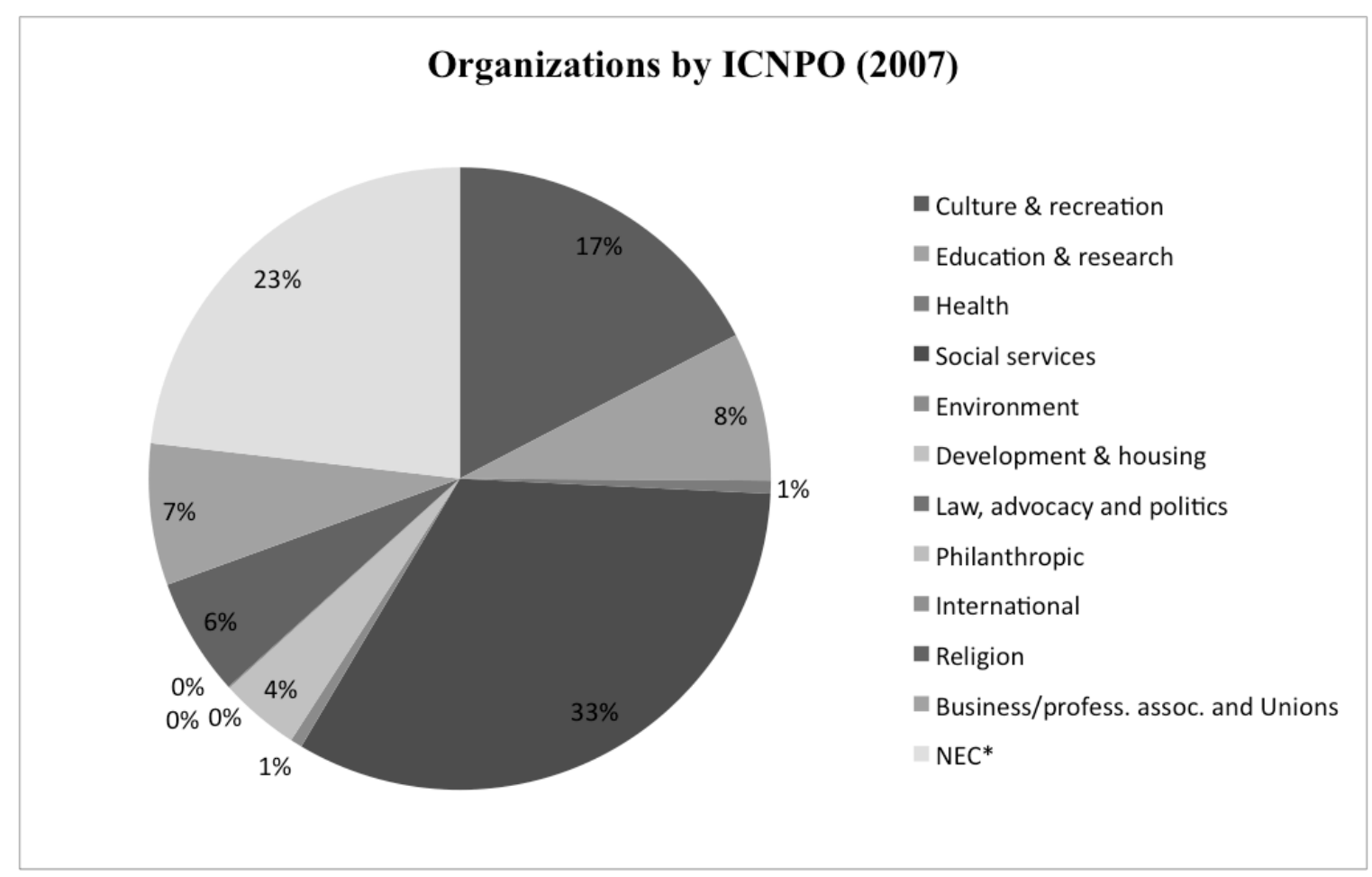

Figure 2: Third sector employment by activity (ICNPO) (in percentage)

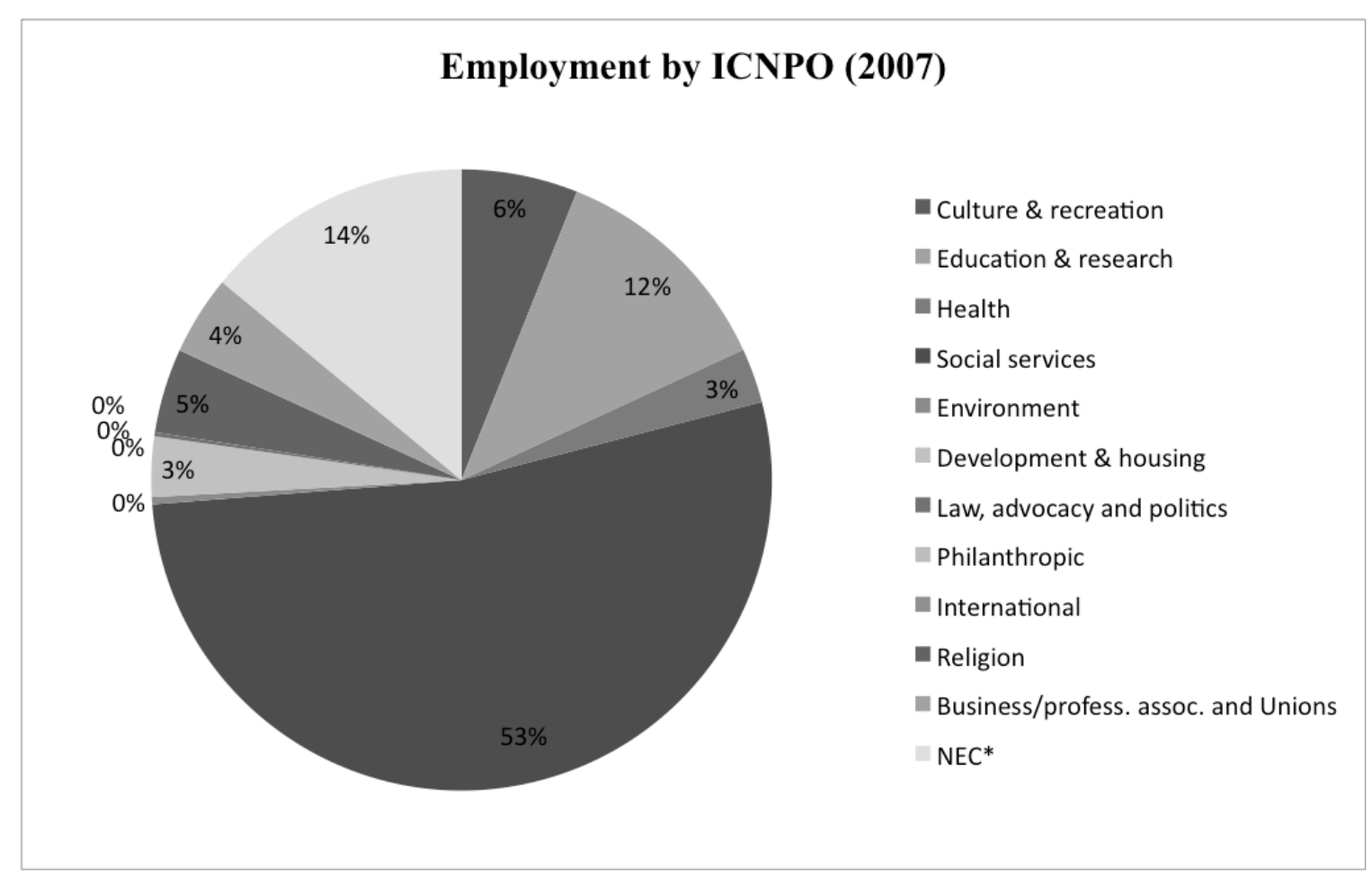


Social services is by large the most prominent activity in the Portuguese third sector, both in terms of number of organizations dedicated to it (32.74\%) and, particularly, in terms of people employed (52.79\%). This confirms the picture set forth by the Johns Hopkins Project's data in 2002, and denotes a further growth in employment level of around $44.51 \%$ in 5 years. In spite of this, Social services come only second in terms of revenue (30.78\%). It has, nonetheless, known an extraordinary growth in revenue in the 10 years leading to 2007 (around 1,507.95\%).

Organizations "Not Elsewhere Classified" (NEC) in terms of activity are the second largest group, making up for $23.17 \%$ of third sector organizations and accounting for $14.01 \%$ of its employment. Although it is awkward that so much of the third sector appears in a residual activity category, this is to a large degree connected to the fact that a full $16.37 \%$ of all third sector organizations (representing 7.84\% of employment) are classified in the CAE Rev.3 residual category "Other associative activities, non-specified" . Moreover, 29.07\% of NEC organizations are cooperatives, which also helps to explain why the larger amount of third sector revenue $(38.51 \%)$ concentrates on NEC organizations. Indeed, 15 of the largest Portuguese Cooperatives in 2007 were in commercial and agricultural activities and their combined revenue amounted to 1,978,024 thousand Euros (INSCOOP, 2008).

Table VII: Distribution and growth of third sector organizations by activity (ICNPO) (2007)

\begin{tabular}{|c|c|c|c|c|}
\hline \multirow{3}{*}{ ICNPO } & \multirow{2}{*}{\multicolumn{2}{|c|}{$\begin{array}{l}\text { Number of organizations } \\
\text { (2007) }\end{array}$}} & \multirow{2}{*}{\multicolumn{2}{|c|}{ Growth }} \\
\hline & & & & \\
\hline & number & percentage & $1997-2002$ & $2002-2007$ \\
\hline 1. Culture and recreation & 1,759 & $17.38 \%$ & $43.32 \%$ & $57.76 \%$ \\
\hline 2. Education and research & 782 & $7.72 \%$ & $4.32 \%$ & $29.47 \%$ \\
\hline 3. Health & 68 & $0.67 \%$ & $9.80 \%$ & $21.43 \%$ \\
\hline 4. Social services & 3,314 & $32.74 \%$ & $50.94 \%$ & $32.83 \%$ \\
\hline 5. Environment & 62 & $0.61 \%$ & $61.90 \%$ & $82.35 \%$ \\
\hline 6. Development and housing & 421 & $4.16 \%$ & $8.73 \%$ & $9.07 \%$ \\
\hline
\end{tabular}


7. Law, advocacy and politics

8. Philanthropic intermed. and voluntarism promotion

9. International

10. Religion

11. Business and professional associations, unions

12. Not elsewhere classified

Total

\section{6}

n.a. ${ }^{a}$

0

620

745

$7.36 \%$

$6.12 \%$

$61.95 \%$

$11.13 \%$

0.00

$-100.00 \%$

2,346

10,123
$23.17 \%$

$35.70 \%$

$51.65 \%$

a. "n.a." - not available

Development and housing organizations (the majority of which $-61.86 \%$ - are also cooperatives) come third in terms of revenue, taking up $17.08 \%$ of third sector income, which is quite remarkable since these organizations represent only $4.16 \%$ of third sector institutions and account for no more than $3.13 \%$ of its employment. This is even more exceptional since their revenue has been growing (by 57\% from 2002 to 2007) while their employment level has fallen (by $27.15 \%$ in those same 5 years).

On the other hand, there are many organizations devoted to Culture and recreation activities, accounting for $17.38 \%$ of the sector, but they are very small and only $6.07 \%$ of people are employed in this activity. This has accentuated over the years, with the number of organizations in these activities growing more than the number of employees. A similar, less stark, situation is found in institutions with a Religious activity, that represent $6.12 \%$ of the number of organizations and only $4.4 \%$ of employment.

Education and research, on the other hand, tend to be the object of larger organizations, accounting for $12.04 \%$ of employment, although only $7.72 \%$ of the number of organizations. The same happens in Health, where a mere 68 organizations $(0.67 \%)$ are responsible for $2.85 \%$ of all third sector employment. Business and professional associations and Unions represented $7.36 \%$ of third sector organizations in 2007 , and employed $4.13 \%$ of the workforce. The 
Environment sub-sector is also one of the smallest, amounting to a mere $0.61 \%$ of organizations, only $0.37 \%$ of employees and $0.47 \%$ of third sector revenue. Law, advocacy and politics organizations are even fewer and have declined 53.85\% from 1997 to 2007. It is most certainly the case that most Law, advocacy and politics organizations (like political parties, for instance) are not specifically classified as such and will therefore fall into the residual NEC category. Organizations classified as having International activities are virtually non-existent, with only one registered on and off, and always with fewer than 20 employees overall.

Table VIII: Distribution and growth of third sector employment by activity (ICNPO) (2007)

\begin{tabular}{|c|c|c|c|c|}
\hline \multirow[t]{2}{*}{$I C N P O$} & \multicolumn{2}{|c|}{$\begin{array}{c}\text { People employed } \\
\text { (2007) }\end{array}$} & \multicolumn{2}{|c|}{ Growth } \\
\hline & number & percentage & $1997-2002$ & $2002-2007$ \\
\hline 1. Culture and recreation & 12,673 & $6.07 \%$ & $5.65 \%$ & $26.64 \%$ \\
\hline 2. Education and research & 25,145 & $12.04 \%$ & $0.71 \%$ & $18.37 \%$ \\
\hline 3. Health & 5,943 & $2.85 \%$ & $-8.33 \%$ & $58.44 \%$ \\
\hline 4. Social services & 110,240 & $52.79 \%$ & $70.62 \%$ & $44.51 \%$ \\
\hline 5. Environment & 782 & $0.37 \%$ & $135.90 \%$ & $183.33 \%$ \\
\hline 6. Development and housing & 6,534 & $3.13 \%$ & $39.42 \%$ & $-27.15 \%$ \\
\hline 7. Law, advocacy and politics & 439 & $0.21 \%$ & $0.19 \%$ & $-15.90 \%$ \\
\hline 8. Philanthropic intermed. and voluntarism & n.a. ${ }^{a}$ & n.a. ${ }^{a}$ & n.a. ${ }^{a}$ & n.a. ${ }^{a}$ \\
\hline \multicolumn{5}{|l|}{ promotion } \\
\hline 9. International & 0 & $0.00 \%$ & $100.00 \%$ & $-100.00 \%$ \\
\hline 10. Religion & 9,178 & $4.40 \%$ & $316.98 \%$ & $82.36 \%$ \\
\hline 11. Business and professional associations, & 8,625 & $4.13 \%$ & $20.97 \%$ & $4.13 \%$ \\
\hline \multicolumn{5}{|l|}{ unions } \\
\hline 12. Not elsewhere classified & 29,260 & $14.01 \%$ & $16.43 \%$ & $33.85 \%$ \\
\hline
\end{tabular}


$\begin{array}{llll}\text { Total } & 208,819 & 100.00 \% & 37.93 \%\end{array}$

a. "n.a." - not available

Table IX: Gross revenue by activity (ICNPO)

\begin{tabular}{lll}
\hline$I C N P O$ & Gross revenue (2007)
\end{tabular}

(1,000 Euros) (percentage) 1997-2002 2002-2007

\begin{tabular}{|c|c|c|c|c|}
\hline 1. Culture and recreation & 343,000 & $3.73 \%$ & $-11.19 \%$ & $44.12 \%$ \\
\hline 2. Education and research & 470,000 & $5.11 \%$ & $59.20 \%$ & $46.88 \%$ \\
\hline 3. Health & 124,000 & $1.35 \%$ & $-4.21 \%$ & $60.21 \%$ \\
\hline 4. Social services & $2,830,000$ & $30.78 \%$ & $192.61 \%$ & $449.51 \%$ \\
\hline 5. Environment & 43,300 & $0.47 \%$ & $150.77 \%$ & $554.43 \%$ \\
\hline 6. Development and housing & $1,570,000$ & $17.08 \%$ & $8.46 \%$ & $57.00 \%$ \\
\hline 7. Law, advocacy and politics & 0 & $0.00 \%$ & $-91.57 \%$ & $-100.00 \%$ \\
\hline \multicolumn{5}{|c|}{ 8. Philanthropic intermed. and voluntarism } \\
\hline promotion & n.a. ${ }^{a}$ & n.a. ${ }^{a}$ & n.a. ${ }^{a}$ & n.a. ${ }^{\mathrm{a}}$ \\
\hline 9. International & 0 & $0.00 \%$ & $-100.00 \%$ & $0.00 \%$ \\
\hline 10. Religion & 73,100 & $0.80 \%$ & $622.83 \%$ & $111.27 \%$ \\
\hline \multicolumn{5}{|c|}{ 11. Business and professional associations, } \\
\hline unions & 200,000 & $2.18 \%$ & $467.47 \%$ & $-39.02 \%$ \\
\hline 12. Not elsewhere classified & $3,540,000$ & $38.51 \%$ & $-16.04 \%$ & $43.90 \%$ \\
\hline \multirow{2}{*}{ Total } & $9,193,400$ & & & \\
\hline & & $100.00 \%$ & $7.33 \%$ & $84.61 \%$ \\
\hline
\end{tabular}

a. "n.a." - not available

So, apart from Social services, Developing and housing and NEC, all the remaining activities have much more modest revenues, neither reaching the 500 million Euros mark, even when they 
represent many of the sector's organizations or a good portion of its workforce. It is also noteworthy that, although they have recovered their revenue from 2002 to 2007, Culture and recreation, Health and NEC register declines in the previous 5 years, evidencing the very recent prosperity of the third sector in Portugal. It also stands out that most of third sector revenue concentrates in activities that are less typical of third sector organizations (namely in NEC activities).

This configuration of the third sector, with a heavy prominence of social service provision and much less significant education, culture and health activities, seems to be quite particular of Portugal. On the one hand, it derives from a welfare system, typical of Southern European countries, that emphasizes monetary transfers, such as unemployment benefits or pensions subsidies, rather than direct public service provision (Laville et al., 1999). On the other hand, it results from the recent government attempts to tackle this deficiency by exploring a "mixed economy of care" policy (Daly and Lewis, 2000, p. 292) whereby it funds private (mostly nonprofit) organizations to provide public services. Although in other countries, like the UK, this has been applied to areas such as health, education, housing and social action (Cunningham, 1999), in Portugal non-governmental organizations have been singled out by the government as key partners in implementing social policy in particular (Conselho de Ministros, 2006, p. 51). Indeed the Government considers that "cooperation, via contracted commitments between the State and IPSSs, has been a privileged format to exercise social action" and is a way to promote "the principle of subsidiarity, for the priority granted to the intervention of those entities with a closer relationship with the citizens" (IGFSS, 2008, p. 370).

As for the Health sector, even though the Misericórdias (Holy Houses of Mercy) ${ }^{\mathrm{d}}$ had an important role up to 1975 , their hospitals were since integrated into the public national health service (Franco et al., 2005), which now prevails and accounts for around $70 \%$ of expenditure in Health (based on the data provided by Pordata, 2010), supplemented by private for-profit institutions that rely on (upsurging) private or (longer standing) occupational compulsory insurance schemes parallel to the public system (Hampton, 1996). In Education and research, the public sector dominates education, taking on $79.05 \%$ of establishments and over $80 \%$ of students in 2007. Third sector schools are a minority, representing $30.2 \%$ of private education institutions and only $6.33 \%$ of all schools in Portugal (considering the numbers provided by the Ministry of Education - GEPE, 2009, pp. 28 and 112). Research expenses, on the other hand, are 
secured mainly by private for-profit companies (51.24\%), with public expenditure remaining at $39.11 \%$, and third sector organization ensuring only $9.66 \%$ of all expenditure in 2007 . Of that amount, 68\% was financed by public funding (based on the data provided by GPEARI, 2009, p. 24).

\begin{tabular}{lrrr}
\multicolumn{3}{l}{ Table X: Government transfers to IPSS organizations (Cooperation Agreements) } \\
\hline $\begin{array}{l}\text { Government transfers } \\
\text { Year }\end{array}$ & $\begin{array}{c}\text { Third sector gross } \\
\text { (1000 Euros) }\end{array}$ & $\begin{array}{c}\text { \% of public } \\
\text { revenue (1000 Euros) }\end{array}$ & $\begin{array}{c}\text { funding } \\
\text { (transfers only) }\end{array}$ \\
& & & $16.03 \%$ \\
\hline 2003 & $841,701.9$ & $5,250,000$ & $15.15 \%$ \\
2004 & 928,565 & $6,130,000$ & $14.63 \%$ \\
2005 & $987,776.6$ & $6,750,000$ & $14.68 \%$ \\
2006 & $1,047,130.1$ & $7,134,465$ & $11.90 \%$ \\
2007 & $1,094,113.6$ & $9,193,400$ & \\
\hline
\end{tabular}

$\overline{\text { b. Source: IGFSS, } 2008 \text { (Social Action Expenses - Cooperation Agreements, p. 368) }}$

Table X shows the Government transfers to IPSS organizations through the Cooperation Agreements that are established annually. Although Cooperation Agreements is not the only way the State funds third sector organizations, it represents $70 \%$ to $75 \%$ of annual current expenses on Social Action programs ${ }^{\mathrm{e}}$ (IGFSS, 2008). As displayed in Table X, the proportion this kind of public funding represents on third sector revenue has been decreasing over the years, and amounts to less than $12 \%$ of the sector's revenue in 2007 , suggesting a gradual decline in the financial dependency of the third sector from the State.

Another feature of the Portuguese third sector is the size of organizations. As apparent in Figure 3 , most of them tend to be very small, with $41.12 \%$ employing fewer than 5 people. Only a quarter $(25.84 \%)$ of all third sector organizations have more than 20 employees. Large organizations, with 250 employees or more, are negligible, at $0.63 \%$.

This is closely tied with the revenue profile of organizations. As shown in Figure 4, nearly half $(42.54 \%)$ of third sector organizations had less than 10,000 Euros of revenue in 2007, and a further half (49.64\%) had between that much and 1 million Euros. Only a diminutive 7.82\% presents revenues above that amount. 
Figure 3: Third sector organizations by size categories

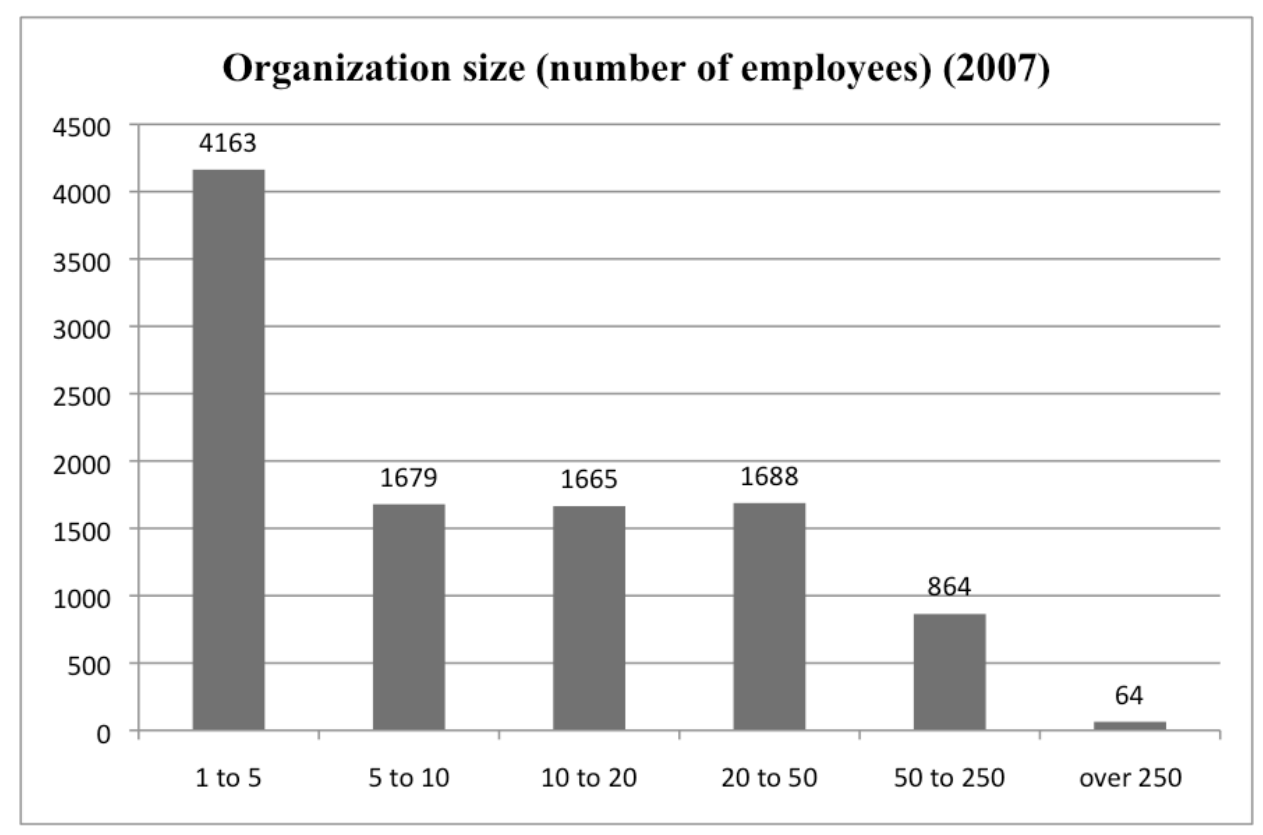

Figure 4: Third sector organizations in different gross revenue categories

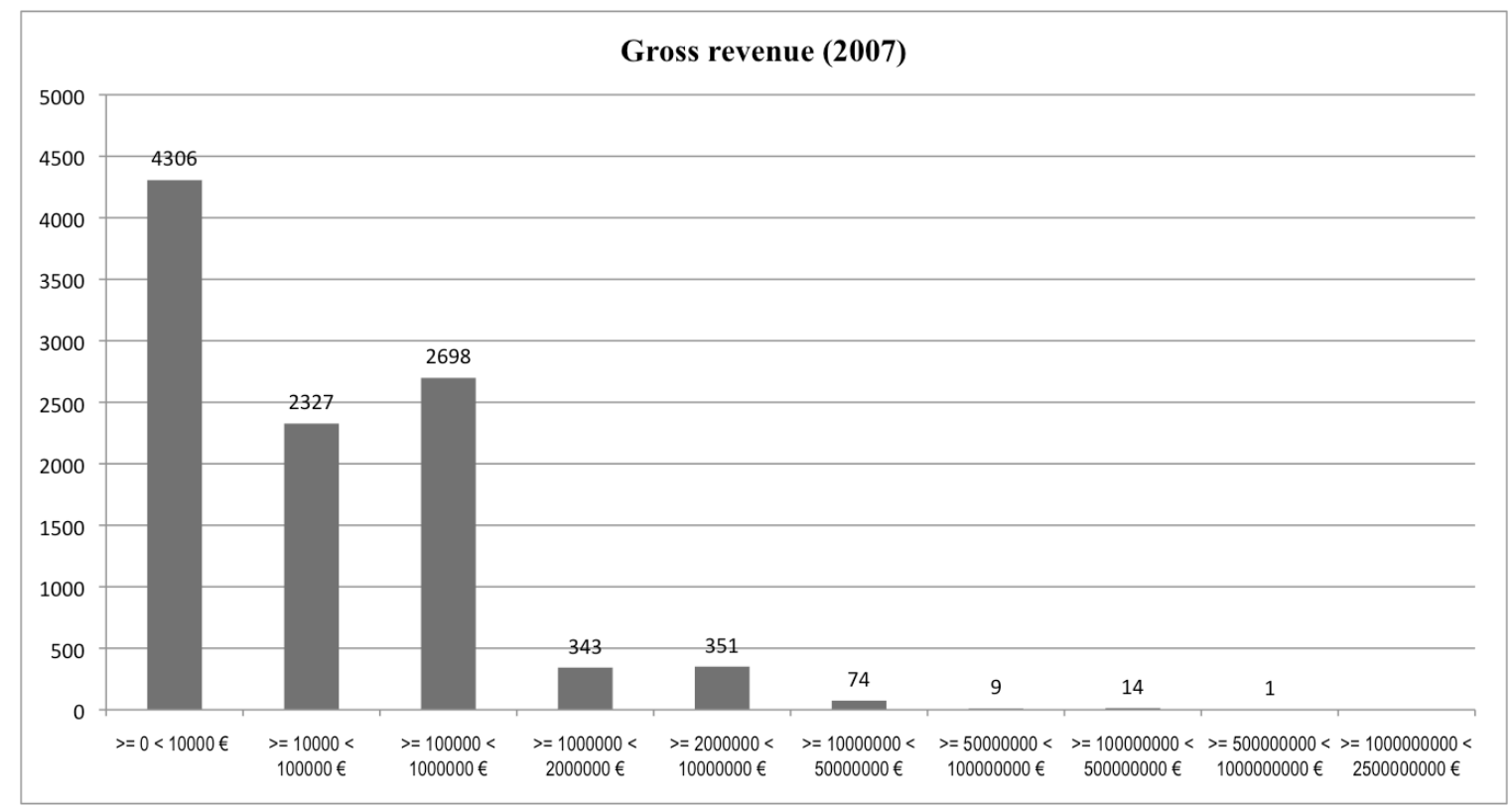

In terms of age, third sector organizations are distributed according to Figure 5. The larger groups concentrate on the 20 to $50(31.23 \%)$ and 10 to 20 years of age $(26.32 \%)$, indicating most third sector organizations are well established. A fair proportion has in fact been around for over $50(12.69 \%)$ or even 100 years $(4.14 \%)$. Most of the latter will be the religious 
Misericórdias, some of which are as old as 500 years. Younger organizations are of course fewer, with only $5.61 \%$ being less than 3 years and a further $4.7 \%$ between 3 and 5 years of age. This can be evidence of the difficulty these organizations have in setting themselves up, which is corroborated by the fact that these categories vary little over time. Despite having grown $16,6 \%$ from 2006 to 2007, organizations less than 3 years had decreased by $11 \%$ from 2005 to 2006. The 3 to 5 year olds decreased $12.5 \%$ from 2006 to 2007 , having fallen $2.3 \%$ in the previous year. This suggests many organizations are not able to survive their initial years. On the other hand, this distribution fits well with the known history of the sector in Portugal (Franco et al., 2005), which was marginal before the 1974 democratic revolution. Since then, and especially after 1986 with the inflow of European Community funding, the third sector has developed considerably. The introduction of the IPSS status in 2002 further boosted the upsurge of publicly funded non-profit organizations.

Figure 5: Third sector organizations by age categories

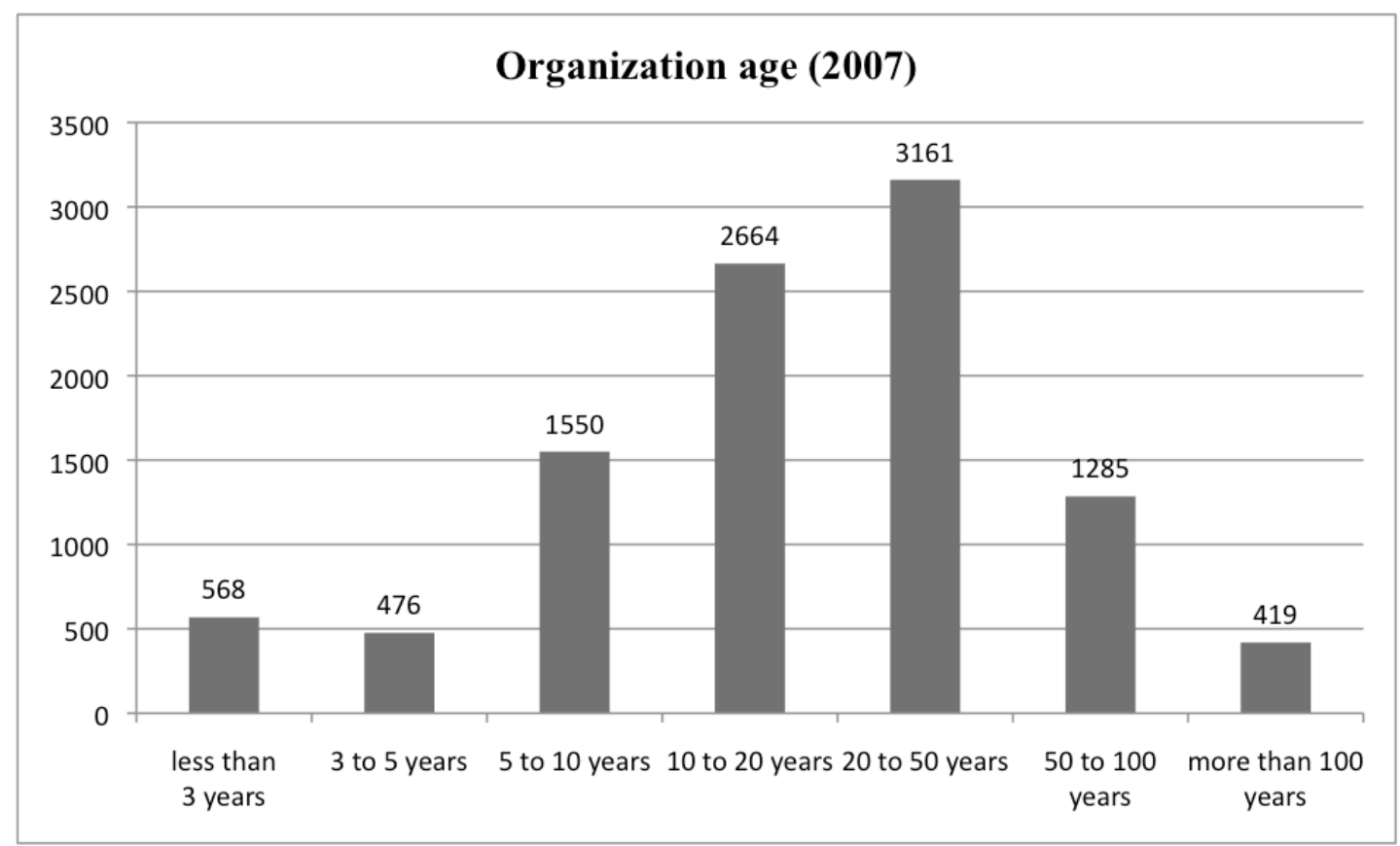

\section{A DECADE IN NUMBERS}

A closer look at a decade of data, from 1997 to 2007, provides an interesting longitudinal analysis. The overall number of organizations has grown about $90 \%$ and the level of 
employment nearly $85 \%$. The sector's revenue has just about doubled, with an increase of $98 \%$ overall. These trends tend to be more pronounced after 2002 rather than in the previous fiveyear period, reflecting the more recent progress of the third sector in Portugal.

When breaking down the analysis into ICNPO categories, however, the unevenness that seems to be typicall of the Portuguese third sector again surfaces. While some activity sub-sectors register remarkable rises, others actually dwindle. Some smaller segments show very significant expansion, although remaining unsubstantial. Such is the case of Religious organizations, that show a striking increase from 1997 to 2007, be it in terms of numbers (448.67\%), employment level $(660.4 \%)$ or revenue $(1,427.14 \%)$. Rather than signifying any great upheaval of religious movements in Portugal, however, this corresponds to a growing formalization of previously irregularly constituted religious organizations. The eligibility to public funding (both national and European) is probably the main reason for this, as the rise in revenue reflects.

The Environment sub-sector also records notable growth - $195 \%$ in terms of organizations, $568 \%$ in employment level and $1,541 \%$ in revenue - expressing the rising concern in society for such issues, even though it remains a diminutive category. Similarly, Culture and recreation grew considerably in organization numbers from 1996-2007 (126.1\%), but less so in terms of employment (33.7\%) and revenue (28\%). In fact, there is a declining trend in the proportion of third sector employment in Culture and recreation, falling from the $8.84 \%$ in 1996 to $5.6 \%$ in 2007.

Social services show the steadiest development in the third sector, as is consistent with the recent government policy. In the10 years under analysis it has grown $100.5 \%$ in number of organizations, $147 \%$ in terms of employment and $1,508 \%$ in revenue. This represents the largest group throughout the period, and its predominance in nonprofit employment has been reinforced from a proportion of $39,47 \%$ in 1997 to $52,79 \%$ in 2007.

In stark contract, organizations in Development and housing, Law, advocacy and politics and International activities have lost some of their employees in the five years from 2002 to 2007 $(27.15 \%, 15.9 \%$ and $100 \%$ respectively), and the latter two have also decreased in numbers (33.3\% and 100\% respectively). And while the revenue level of organizations in Development and housing rose $57 \%$ in that period, in the case of Law, advocacy and politics organizations it has fallen from 1.6 million Euros in 1997 to literally zero in 2007, perhaps indicating classification problems. No more than one non-profit organization has registered as having 
International activities during this period, and no revenue is registered since 1997.

Variations are much less dramatic in the remaining activity sub-sectors. Business and professional associations and Unions have grown in the 10 years leading to 2007 some $20.16 \%$ in number and $25.97 \%$ in terms of people employed, but their relative weight in the third sector has been declining. Their revenue also decreased from 2002 to 2007 (by 39.02\%). Education and research nonprofits have increased both in numbers and in employment level during the period at a similar rate $(42,7 \%$ and $40,7 \%$ respectively), although they have lost some of their relative weight in the sector, falling from an employment percentage of $18,62 \%$ in 1997 to only $12,04 \%$ in 2007 . Health organizations, in turn, have registered a $62,6 \%$ rise in employment level, but remain a (diminishing) minority, representing only $2,85 \%$ of third sector employment. The residual NEC category has been increasing below the sector's overall average growth, $67,74 \%$ in numbers and only $23,38 \%$ in employment. Consequently, its relative weight has decreased somewhat from $21.41 \%$ of all third sector organizations in 1997 to $23,17 \%$ in 2007 , and from $16.57 \%$ of its workforce to $14,01 \%$. More significantly, and despite growing some 43.9\% from 2002 onwards, NEC organizations' slice of the sector's revenue has fallen from a preponderant $63.15 \%$ in 1997 to $38.51 \%$ ten years later.

\section{CONCLUSIONS}

This paper seeks to provide an overview of the third sector in Portugal, as well as analyze its progress in the 10 years between 1997 and 2007. Unlike previous studies this one uses data gathered in a universal survey of all private organizations with one or more employees (Quadros de Pessoal) instead of relying on sample surveys or estimated figures. The definition of the third sector is based on the legal status (Laville et al., 1999).

A snapshot analysis of 2007 data reveals that the third sector in Portugal included 10,123 organizations employing 208,821 people and accounting for 4\% of the country's global employment. Total gross revenue amounted to 9,193,400 million Euros, which represents 5.64\% of Portugal's GDP for that year. The majority of these organizations are well established in society, having been around for at least 10 years. Around a quarter of them are younger than 10 years, and many seem to struggle to survive their initial stage. They also tend to be very small, with nearly $60 \%$ employing less than 10 people and only around 9\% employing more than 50 . Accordingly, most have very low revenues, with 42.54\% raising less than 10,000 Euros 
annually and only $7.82 \%$ with an income of 1 million Euros or more.

The asymmetries within the sector stand out quite distinctly. Social services is by large the activity that congregates more third sector organizations (32.74\%) and even more of its workforce $(52.79 \%)$, accounting for $30.78 \%$ of the sector's revenue. To lower degrees, Culture and recreation also make for a substantial share of third sector organizations $(17.38 \%)$, and Education and research contribute to a significant part of the employment (12.04\%), but Health is quite diminutive comparing to other countries (Franco et al., 2005). This reflects the recent government policy that has elected to directly provide education and health services while contracting out and financing the delivery of social services by third sector institutions through Cooperation Agreements.

Unfortunately, $23.17 \%$ of third sector organizations, $14.01 \%$ of its employment and $38.51 \%$ of the sector's revenue concentrates in "Not elsewhere classified" activities. This can be partly explained by the fact that over $16 \%$ of third sector organizations are classified in a residual unspecified activity category, and also that a group of large high revenue cooperatives fall into this category. This lends support to the reservations reported by Chávez and Monzón-Campos (2008) as to the inclusion of cooperatives in the third sector. Indeed most (and in particular the largest) cooperative societies in Portugal tend to undertake activities less typical of the third sector such as commerce and agriculture. The fact that INSCOOP (2008) uses the term "cooperative companies" might also be revealing of the distancing of these organizations from the third sector ethos.

The evolution from 1997 to 2007 is also quite revealing and highlights the disparities across the sector. The overall number of organizations has grown about $90 \%$ and the level of employment nearly $85 \%$. But these rises have concentrated on Religious institutions, followed by Environment, Culture and recreation and Social services. In terms of revenue, growth is very significant in activities such as the Environment, Social services and Religion but the Law, advocacy and politics and International segments lose their income altogether.

Such numbers show an inequivocal trend in the Portuguese third sector towards gaining importance in the economy, both in terms of employment level and especially in terms of revenue. The data readily available on public funding seem to indicate these organizations are becoming more autonomous from the State, as their revenue growns despite receding public funding. Sustainability and financial independence from public funding has been identified as a 
major challenge facing the third sector in European countries (Anheier, 2002). It would be interesting to follow this on and investigate whether this corresponds to a real increase in autonomy, or a transfer of public funding from the Portuguese State to European Union funds. Also, the sector remains quite unbalanced, with this trend towards growth and apparent independence to be more characteristic of Social services and cooperatives rather than a uniform and unified movement. Again, monitoring the evolution of third sector composition will be essential to understand its dynamic role in Portuguese economy and society.

\section{Notes}

a. In Portugal, there is a special status of IPSS (Instituição Privada de Solidariedade Social social solidarity private institutions) granted by the government (through the Ministry of Labor and Social Solidarity) to third sector organizations that apply and meet certain requirements. These organizations are eligible to celebrate Cooperation Agreements and Management Agreements with the government, through which it funds the provision of public services by private organizations.

b. Indeed, the very expression used to refer to these kinds of organizations is considerably diverse, varying from nonprofit, voluntary, non-governmental and civil society to third sector or third system, each with their specific idiosyncrasies. In this paper, third sector is the preferred expression, albeit in a fairly inclusive conceptualization that covers cooperatives and mutual aid associations. However, it is not as inclusive as the more consensual Social Economy conceptualization, and thus excludes financial mutualities and private companies that are "created to meet their members' needs through the market" (Cháves and Monzón-Campos, 2008, p. 8).

c. Rev. 3 of CAE, used since 2007, actually improves on this from Rev. 2.1. In 2006, nearly $25 \%$ of third sector organizations (corresponding to $10.37 \%$ of third sector employment) were registered in residual CAE categories (namely "Other associative activities, non-specified” and "Other service activities, non-specified").

d. The Holy Houses of Mercy (Santas Casas de Misericórdia) are Church related charity institutions, the history of which goes back to the XV century in Portugal, that are committed mainly to social assistance, health care and poverty relief. There are around 400 Misericórdias in Portugal in the present day. 
e. The public funding of third sector organizations here considered includes only government transfers in the Social action activity, which are the only data made available to the wider public. It does not include transfers to other activities (like education or culture) nor does it include sales to the government by third sector organizations, which are not disclosed.

\section{References}

Anheier, H. K. (2002). The third sector in Europe: Five theses. Civil Society Working Paper 12, Centre for Civil Society, London: London School of Economics.

Blanchard, O. and Portugal, P. (2001). What hides behind an unemployment rate: comparing Portuguese and U.S. labor markets. The American Economic Review, 91(1), 187-207.

Carvalho, A. C. (2008). Casas do povo - sua criação e direito vigente. Retrieved January 20, 2010, from http://www.casapovoalagoa.pt/main.asp?pag=casas_povo.asp

Chávez-Ávila, R. and Monzón-Campos, J. L. (2005). The social economy in the European Union. CIRIEC N ${ }^{\circ}$. CESE/COMM/05/2005 - EESC.

Cháves, R. and Monzón-Campos, J. L. (2008). The social economy in the European Union. (Working paper $\mathrm{N}^{\circ}$ 2008/02), Liège: CIRIEC.

CIRIEC (2000). The enterprises and organizations of the third system: a strategic challenge for employment (Project Report). Liège: CIRIEC.

Conselho de Ministros (2006). Portugal - Grandes opções do plano - principais linhas de acção para 2007. Lisboa: Conselho de Ministros.

CRP (Constituição da República Portuguesa) (2005). Artigo 82 - Sectores de propriedade dos meios de produção. Retrieved July 7, 2009, from http://www.parlamento.pt/Legislacao/Paginas/ConstituicaoRepublicaPortuguesa.aspx\#art82 Cunningham, I. (1999). Human Resource Management in the voluntary sector: challenges and opportunities. Public Money and Management, 19(2), 19-25.

Daly, M. and Lewis, J. (2000). The concept of social care and the analysis of contemporary welfare states, British Journal of Sociology, 51(2), 281-298.

Defourny, J. and Develtere, P. (2000). The social economy: the worldwide making of a third sector, in Strategies and Tools against Social Exclusion and Poverty. Research Group on Civil Society and Social Economy, Geneva: ILO, 1-37. 
European Commission (2003). Commission recommendation 2003/361/EC of 6 May 2003.

Retrieved November 10, 2008, from http://eur-

lex.europa.eu/LexUriServ/site/en/oj/2003/1_124/1_12420030520en00360041.pdf

Ferrera, M., Hemerijck, A., and Rhodes, M. (2000). The future of social Europe: recasting work and welfare in the new economy (Report for the Portuguese Presidency of the European Union).

Retrieved February 19, 2010, from http://www.aueb.gr/deos/MASTER-

GR/Ferrera_Hemerijck_Rhodes.pdf

Franco, R. C., Sokolowski, S. W., Hairel, E. M. H., and Salaman, L. M. (2005). The Portuguese non-profit sector in comparative perspective. National Report. The Johns Hopkins Comparative Non-profit Sector Project.

GEPE (Gabinete de Estatística e Planeamento da Educação/Ministério da Educação) (2009). Educação em números - Portugal 2009, Lisboa: Editorial do Ministério da Educação.

Gomes, R. T., Lourenço, V., and Martinho, T.D. (2006). Entidades culturais e artísticas em Portugal. Observatório das Actividades Culturais. docs - Documentos de Trabalho, 1-163. Hodgkinson, V. A. (1999). Defining the nonprofit sector cross-nationally - differing cultures, roles, and histories. Nonprofit Management and Leadership, 10(2), 209-214.

GPEARI (Gabinete de Planeamento, Estratégia, Avaliação e Relações Internacionais) (2009), Sumários estatísticos - IPCTN.07. Lisboa: GPEARI.

IGFSS (Instituto de Gestão Financeira da Segurança Social) (2008). Conta da Segurança Social 2007. Lisboa: Ministério do Trabalho e da Segurança Social.

INE (2008a). Estatísticas do emprego, $4^{\circ}$ trimestre 2007. Boletins e Folhas de Informação Rápida. Lisboa: INE.

INE (2008b). Contas nacionais $-4^{\circ}$ trimestre de 2007 e Ano 2007. Destaque 10 de Março de 2008. Lisboa: INE.

INSCOOP (2008). As 100 maiores empresas cooperativas - Ranking. Retrieved February 8 , 2010, from http://www.inscoop.pt/Inscoop/actividades/publicacoes/docs/100maiores/Edicao2008/Ranking 100_2009.pdf

Laville, J., Borzaga, C., Defourny, J., Evers, A., Lewis, J., Nyssens, M., and Pestoff, V. (1999). Third system: a European definition (Report of the Capitalisation Group - Third System and Employment Pilot Action) Brussels: European Commission DG Employment and Social 


\section{Affairs.}

Martins, P. S. (2004). Industry wage premia: evidence from the wage distribution. Economic Letters, 83(2), 157-163.

Mata, J. and Portugal, P. (2000). Closure and Divestiture by Foreign Entrants: The Impact of Entry and Post-Entry Strategies. Strategic Management Journal, 21(5), 549-562.

Pordata - Base de dados Portugal Contemporâneo (2010), Health - Expenditure, Retrieved March 2, 2010, from http://www.pordata.pt/azap_runtime/?n=4

Salamon, L. M. and Anheier, H. K. (1997). Defining the nonprofit sector: A cross-national analysis. Manchester, UK: Manchester University Press.

United Nations (2003). Handbook on non-profit institutions in the system of national accounts. New York: United Nations. 